\title{
The basis for placing a roadside service object in a municipal area
}

\author{
Lyudmila Oznobihina ${ }^{1, *}$ \\ ${ }^{1}$ Industrial University of Tyumen, 625001, Tyumen city, Russia
}

\begin{abstract}
As international experience and Russian practice of creating an investment climate show, the effectiveness of the efforts of the local government level is of decisive importance when investors choose their production locations and implement other direct investments. The paper discusses topical issues of investment attractiveness of placing a roadside service facility on a land plot. Issues related to the implementation of the investment program of the Berdyuzhsky municipal district of the Tyumen region, namely the development of roadside services, including the analysis of urban planning documentation and territories of municipalities, urban planning (territorial) planning, planning and development of the territory, as well as actions to establish requirements for the considered land plots.
\end{abstract}

\section{Introduction}

The transport process cannot be carried out without modern highways, as well as without their arrangement, roadside service facilities. The development of road service facilities is one of the key areas of the Russian Transport Strategy for the period up to 2030, as well as one of the most promising tasks of Rosavtodor. The range of both freight and passenger traffic is increasing every year. At present, the rapid development of the infrastructure of road service facilities is noted on many highways in Russia [1].

The city-forming sectors of the Berdyugsky region are: agricultural production, which employs 11 enterprises, industry, small business development, construction, and the main component of the positive development of the territory is the standard of living of the population. The location of the district, natural and climatic conditions - all this is a positive factor for progress in the implementation of further goals of the district. City-forming enterprises provide an opportunity not only to improve the economic potential of the region, but also the social one: provision of jobs (reduction of unemployment), housing, cultural development and recreation, high-quality food, physical development. The region's economy is characterized by a significant proportion of industries focused on the use of road transport, the efficiency of which is associated with the level of development of highways [2].

In order to increase the level of socio-economic development of the territory in the Berdyuzhsky municipal district, it was proposed to implement an investment project for the

\footnotetext{
*Corresponding author: oznobihinala@tyuiu.ru
} 
construction of a roadside service facility. The main goal of the investment policy is to increase investments in the economy of the district, contributing to the intensive development of the production sector, modernization of production, increasing the competitiveness of goods and services produced in the district, and increasing incomes of the population, enterprises and the municipal budget. There are infrastructure sites for the implementation of investment proposals and projects in the region. In order to increase investment attractiveness, create favorable conditions for entrepreneurial and investment activities in the Berdyuzhsky municipal district of the Tyumen region, the regulation "Support of investment projects implemented and planned for implementation in the Berdyuzhsky municipal district of the Tyumen region" was approved. According to the adopted regulations, the Deputy Heads of Administration of the Berdyuzhsky Municipal District, who oversee the work of the Department of Economics, the Department of Municipal Property and Urban Planning Policy and the Department of Construction and Housing and Communal Services, resolve issues of investment and economic development and determine the employees of the Administration of the Berdyuzhsky Municipal District responsible for working with investors [3].

The importance of developing roadside service in the Tyumen region is confirmed by the active actions of the regional government, development institutions (the Tyumen Region Investment Agency Fund) and a number of federal authorities and institutions authorized to protect the rights of entrepreneurs. The main goal of the development of roadside service in the Tyumen region is in the following areas: solution of problematic issues of existing facilities: registration of land plots and property rights, solution of issues related to registration of a road junction, and so on; expansion and modernization of existing roadside service facilities: an increase in parking for vehicles, the introduction of new services: a bathhouse, a hotel, trade and so on; search for new investors for finished land plots; creating roadside markets [4]. The implementation of this project will have the most positive impact on the development of the municipal district and rural settlement. In order to search for potential sites for the placement of a roadside service facility, an analysis of urban planning documentation and the territory of the Berdyuzhsky municipal district was carried out. Territories of Berdyuzhsky and Peganovsky rural settlements are suitable for placing a roadside service facility. During the analysis of these potential sites, it was revealed that the territories were not provided with documentation [5]. It was necessary to develop documentation for the planning of the territory of potential sites. Preparation of documentation for the planning of the territory is carried out in order to ensure the sustainable development of territories, including the allocation of elements of the planning structure, the establishment of the boundaries of land plots, the establishment of the boundaries of the zones of the planned location of capital construction objects. When choosing land plots, various factors were taken into account, which are stipulated in the Decree of the Government of the Russian Federation of October 29, 2009 No. 860 "On the requirements for the provision of public highways with road service facilities located within the boundaries of right-of-way." : visibility on the road; other road safety conditions; conditions for the use and maintenance of the road and the structures and other objects located on it [6].

The site intended for construction must meet sanitary requirements in terms of direct sunlight, natural ventilation and be located as close as possible to utilities [7]. It is necessary to ensure a rational relationship between the site and residential areas with minimal time spent on labor movements, therefore, the proximity to the boundaries of the settlement had a significant impact on the choice of the land plot. For a comparative analysis, two land plots were selected that are suitable for placing a roadside service facility Figure 1, Table 1. According to the urban planning regulations, the land plot No.1 is located in the zone of the engineering and transport infrastructure, which is intended for the 
placement and operation of structures and communications for power supply, water supply, sewerage and wastewater treatment, gas supply, heat supply, communications and transport infrastructure facilities, including automobile, river, air and pipeline transport, as well as for the establishment of sanitary protection zones of such facilities in accordance with the requirements of technical regulations and territories necessary for their maintenance and protection. On this land plot, there are asphalt-paved access roads, which is a huge plus for the location of a roadside service facility and will reduce the cost of implementing an investment project. The land plot has an advantageous location, as it is located at the entrance to the settlement, and is also located directly at the federal highway [8].

Table 1. Characteristics of the land plot.

\begin{tabular}{|c|c|}
\hline Indicators & Characteristics \\
\hline Location (address) & $\begin{array}{c}\text { Tyumen region, in the eastern part of the village. } \\
\text { Berduzhier. }\end{array}$ \\
\hline Accessroads & Access roads are provided with asphalt pavement. \\
\hline Powersupply & $\begin{array}{l}\text { VL } 10 \mathrm{kV} \text { overhead line runs in the immediate } \\
\text { vicinity of the site. No construction required. }\end{array}$ \\
\hline Gassupply & Gas passes in the immediate vicinity of the site. \\
\hline Watersupply & $\begin{array}{l}\text { The water supply runs from the south side of the } \\
\text { site. }\end{array}$ \\
\hline Area & 13,5 hecatar \\
\hline Landcategory & Landsofsettlements \\
\hline Permitteduse & For the construction of roadside service facilities. \\
\hline Landsurveying & Carriedout \\
\hline Cadastralnumber & 72:04:0601003:1305 \\
\hline
\end{tabular}

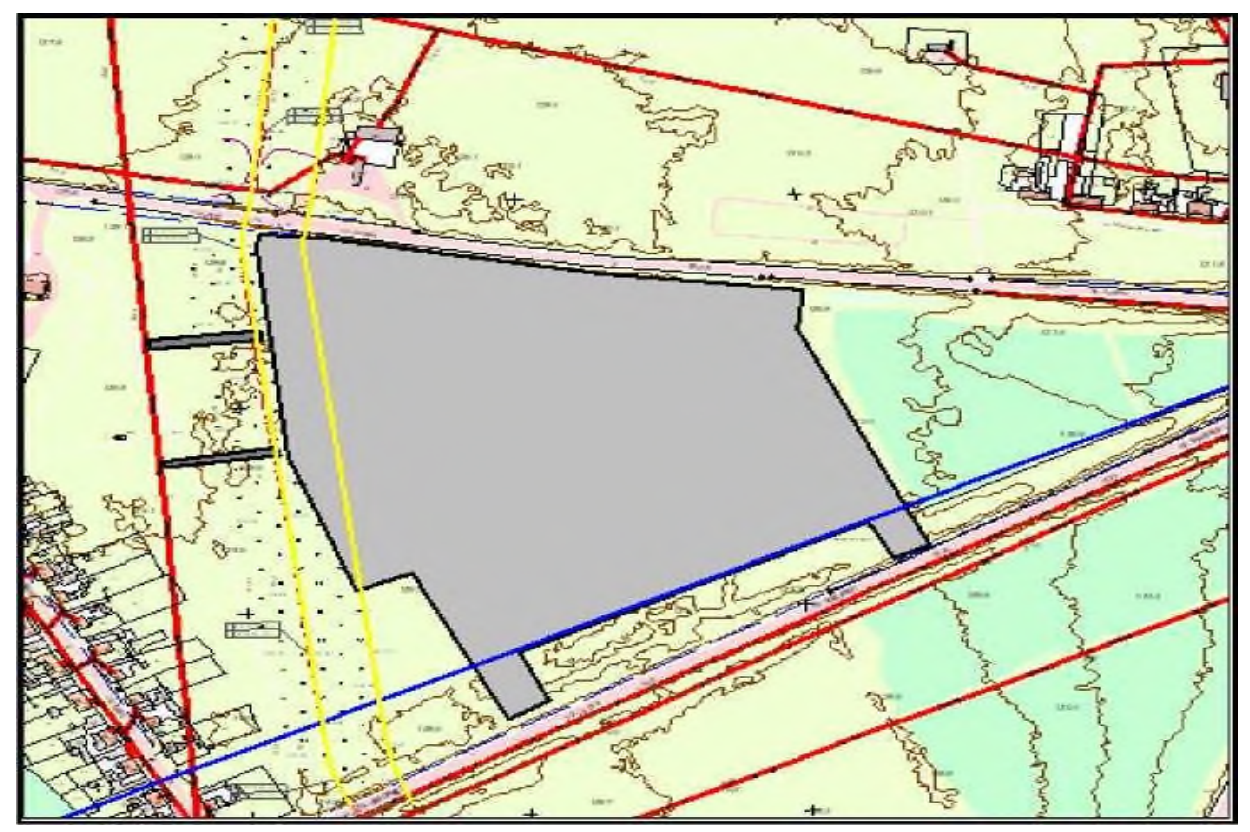

Fig. 1. Characteristics and location of the land plot №.1. 
Table 2. Characteristics of the land plot №.2.

\begin{tabular}{|c|c|}
\hline Indicators & Characteristics \\
\hline Location (address) & $\begin{array}{c}\text { Tyumen region, Berdyuzhsky district, Okunevo } \\
\text { village }\end{array}$ \\
\hline Accessroads & $\begin{array}{c}\text { A paved road (gravel) runs southeast of the site } \\
\text { at a distance of } 450 \mathrm{~m} \text { from it. }\end{array}$ \\
\hline Powersupply & $\begin{array}{c}\text { A } 10 \mathrm{kV} \text { overhead line runs southeast of the site } \\
\text { at a distance of } 450 \mathrm{~m} \text {. From him. }\end{array}$ \\
\hline Gassupply & $\begin{array}{c}\text { The gas pipeline runs north-east of the site at a } \\
\text { distance of } 2500 \mathrm{~m} . \text { Fromhim. }\end{array}$ \\
\hline Watersupply & Missing. Well drilling is possible. \\
\hline Area & Agriculturalland \\
\hline Landcategory & $\begin{array}{c}\text { For the construction of roadside service } \\
\text { facilities (parking lot for motor vehicles). }\end{array}$ \\
\hline Permitteduse & Carriedout \\
\hline Landsurveying & $72: 04: 0511001: 709$ \\
\hline Cadastralnumber &
\end{tabular}

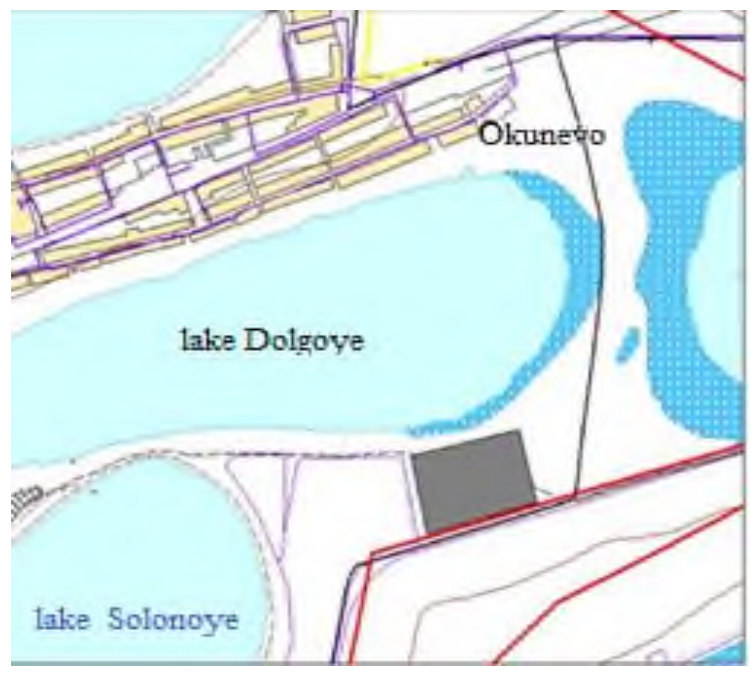

Fig. 2. Characteristics and location of the land plot №.2.

Consider the characteristics of the land plot №. 2, which is located on agricultural land Figure 2, Table 2. It is necessary to transfer agricultural land to industrial land. In accordance with the Law of the Tyumen Region dated October 5, 2001, No. 411 (as amended on September 6, 2017) "On the Procedure for the Disposition and Management of State Lands of the Tyumen Region", the transfer from one category to another of lands or land plots owned by the Tyumen Region region, agricultural land, with the exception of those in federal ownership, is carried out by the Department of Property Relations of the Tyumen region. According to the Federal Law of December 21, 2004 No. 172-FZ (as amended on June 29,2017 ) "On the transfer of land or land plots from one category to another", the transfer of agricultural land from agricultural land to another category is allowed in the event placement of industrial facilities on land, the cadastral value of which does not exceed the average level of the cadastral value in the municipal district in the absence of other options for the location of these facilities. It is necessary to carry out the procedure for delineating state ownership of land [9].

According to the Law of the Tyumen region dated December 26, 2014, No. 125 (as amended on March 23, 2018) "On the redistribution of powers between local government 
bodies of the Tyumen region and state authorities of the Tyumen region and on amending article 14 of the Law of the Tyumen region" On the order of disposal and management of state lands of the Tyumen region "" the powers of the bodies of state power of the Tyumen region include the powers of local authorities of urban districts, municipal districts of the Tyumen region to provide land plots, state ownership of which is not delimited (including the formation of land plots, including approval layouts of a land plot or land plots on the cadastral plan of the territory), for the implementation of large-scale investment projects. When transferring land from one category to another and delineating land, it is necessary to provide compensation payments. Since there are no engineering communications on this land plot, it is required to provide for the costs of their implementation. The remoteness of engineering communications from the land plot can create certain difficulties when placing an object [10]. As a result of the analysis of two potential land plots selected for the placement of the roadside service facility, land plot No. 1 was determined as the most efficient and profitable. The object of the study is located near the settlement, which will ensure the minimum time spent on labor movements [11].

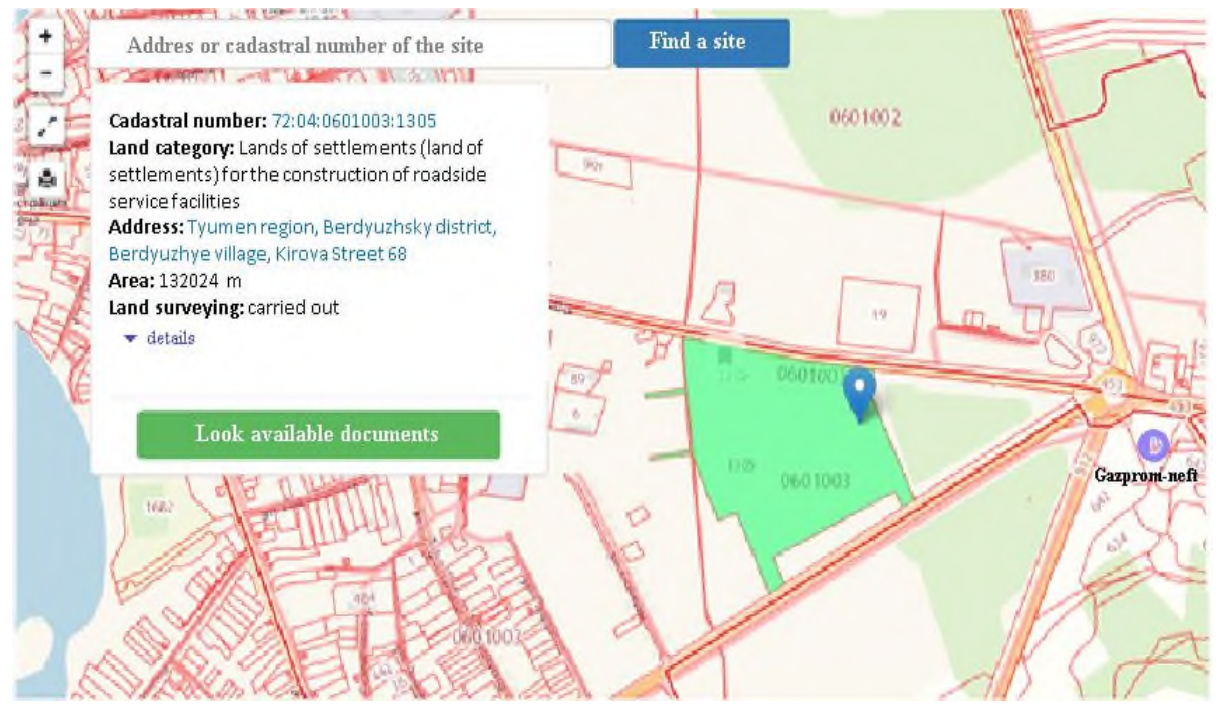

Fig. 3. Fragment of a public cadastral map.

Engineering structures do not need additional investments, compensation payments are not required. A fragment of the public cadastral map is shown in Figure 3. Consequently, after obtaining state registration of rights to real estate, engineering preparation of the territory, build a roadside service facility on land plot №. 1 .

Thus, when searching for land plots for the placement of a roadside service object, an analysis of urban planning documentation and territories of municipalities was carried out. The study revealed a low level of provision with updated urban planning documentation. Berdyuzhsky district is one of the developing districts of the Tyumen region, the development of the economy needs the formation and implementation of a purposeful and comprehensive investment policy. Increasing investment attractiveness and the level of creditworthiness are becoming important factors in attracting financial resources for the development of the district's economy and the implementation of investment projects, which will expand the tax base and increase the flow of revenues to the budget. 


\section{References}

1. A. Ermakova, T. Nurullina, Moscow economic magazine 10, 49 (2019)

2. A. Ermakova, Moscow economic magazine 2, 19 (2020)

3. A. Ermakova, Y. Zubareva, Strategic development of rural areas in the South of the Tyumen region (Tyumen industrial University, Tyumen, 2017)

4. A. Ermakova, Moscow Economic Journal 10, 50 (2019)

5. Y. Zubareva, I. Pivovarova, The national composition of the self-employed population of Siberia (according to the results of the census of 1897) 3, 129-134 (2019)

6. O Kirilova, O. Ustinova, Voprosy istorii 9, 34-44 (2019)

7. I. Pivovarova, Y. Putilina, Y. Zubareva, A. Mamadaliev, Russian Historical Journal 49(3), 1216-1223 (2018)

8. L. Oznobihina, Moscow Economic Journal 1, 7 (2020)

9. L. Oznobihina, S. Odintseva, Modern issues of land management, cadastre and land monitoring materials of the regional scientific and practical conference, 125-130 (2016)

10. L. Oznobihina, Moscow Economic Journal 2, 20 (2020)

11. A. Oznobihina, L. Oznobikhina, Moscow Economic Journal 1, 8 (2019) 